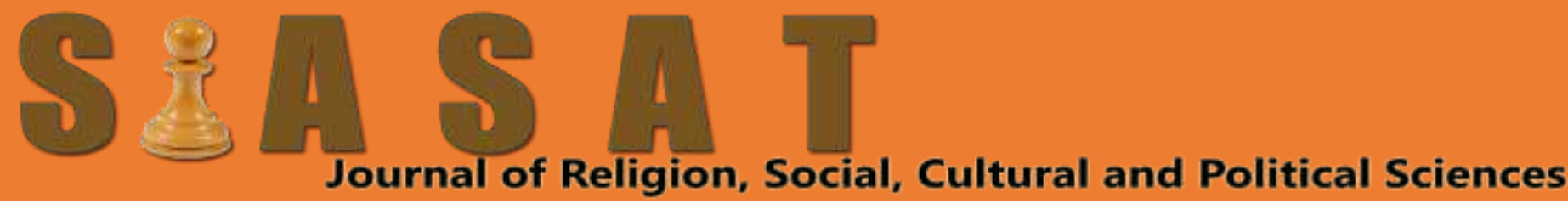

\title{
Gender Dynamics in Islamic Law Perspective: Descriptive Study in Idaman Villlage, Banten
}

\author{
Tolkah \\ Sekolah Tinggi Ilmu Hukum Gunung Jati, Tangerang, Indonesia \\ dr.tolkah@gmail.com
}

Abstract

Gender differences and cultural structures in the ideal village area classify the status of men and women. Islamic law has a different point of view in seeing gender status in Indonesian society. This study looks at the dynamics of gender in the village of ideal banten from the perspective of Islamic law. This study used a descriptive method with a qualitative approach, while the determination of the informants was purposvie sampling by considering traditional leaders, village heads and communities and finally data collection through primary and secondary. The results showed that gender dynamics inequality as a problem in the Islamic world, as well as the dark side of masculine-related behaviors cannot only be approached through the perspective of women alone.
Keywords

gender, Islamic law, inequality

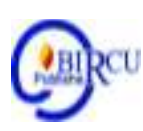

\section{Introduction}

Gender in Islamic law provides an interesting perspective, so that when gender issues are raised, what comes to our mind is discrimination against women, restrictions and the elimination of rights against women (Talbot, 2019). Gender has been championed by several groups, both from academia and from those who view Islam as the religion that triggers the presence of this gender issue in this world (Ruble, 2007). Islam does not differentiate between rights and obligations that exist in human anatomy, rights and obligations are the same in the view of Islamic law for the two different anatomies, men and women (Charrad, 2011). Islam puts forward the concept of justice for anyone and for anyone regardless of their gender (Platt, 2017).

Islam is a religion that has freed the shackles of the tyranny of slavery, equality of rights and has never prioritized and prioritized just one anatomy, Islam exists as a religion that spreads love for everyone, Islam is also a religion that is guided by the Koran and the hadiths used as a teaching guide for humans in living life, including understanding gender (Cholil, 2013). In line with this, women's oppression is needed because it brings benefits. First, the exploitation of women in the household will make bad men in the pub more productive. Second, women also play a role in the reproduction of cheap labor, thus allowing lower labor prices. Cheap wages for labor benefit capitalism.

However, in today's era there have been many changing views on gender dynamics, starting from the view that women only have the right to take care of the house and always be at home, while men are creatures who have to be outside the house, then with the changing times and emancipation causes women to ultimately obtain the same rights as men (Abidin, 2017). 
This shows that women have the same position in doing business and working, it's just that the culture of the community considers women to be at home taking care of the household (Charrad, 2009). But with the progress of time, women and men can work together in various fields of life (Torab, 2006). In other words, that women need to have the opportunity to demonstrate their ability to fulfill development in accordance with common aspirations. It is in line with the opinion (Bachtiar, 2012) that the ability of women is increasingly visible in various kinds of jobs and professions, and the quality of their work is not lower than that of men, unless the job requires large physical labor, such as port labor. On the other hand, there are jobs that are more appropriate for women because they are more demanding for female characteristics (Sayidiman, 1987).

Therefore, among the mustadh'afin community groups who are most fortunate with the presence of Islam are women. In Islam, women are humanized, just like men. The practice of female infanticide, which commonly occurs among the jahiliyah, has been totally stopped (Musda, 2003). Even the Qur'an mentions a baby girl being born as happy news from Allah, and therefore it is not fitting for her to be greeted with shame as was the case before. (Surah An-Nahl 16: 58-59). Which means: And when someone of them is given news with a (birth) daughter, black (red) face, and He is very angry. He hid himself from the crowd, because of the bad news that was given to him. Will He take care of it by enduring humiliation or will He bury it in the ground (alive)? Know, how bad what they charge.

In the context of Islamic law, the issue of gender dynamics is one clear example of how the text of the holy book, the interpretation of it, and the social context that surrounds often clashes and tensions (Hadi, 2016). Gender dynamics are actually born from the critical awareness of women towards the backwardness of their people. Islam as a religion that brings mercy to all nature has teachings and rules of law which are always oriented to the benefit of humans. Every law that is prescribed must contain the value of benefits returned to humans, it's just that the value of benefits is sometimes not found after reasoning. But generally, in the applied laws can be found the value of benefits which is also called the wisdom of the law or the philosophical basis of law (Helmi et al, 2019). According to Islamic law, Punishment is a reward for the perpetrators of organized crime by Personality 'which are generally aimed at the welfare of the community (Munawarsyah et al, 2018).

The ideal village has a unique phenomenon in building a cultural process of division of labor between women and men, women are taught to work without any restrictions with men, whereas this contradicts the cultural values of their ancestors, this makes research interesting, so this research will explain how the gender dynamics in the perspective of Islam in the ideal village of Banten Province.

\section{Research Methods}

The method used in research on Gender Dynamics in Islamic Law is a descriptive method using a qualitative approach. Descriptive method is used in order to obtain a description of the condition of the subject or object of research, whether it can be humans, institutions, and society based on data and facts that are visible and what they are. Descriptive method is a method that guides researchers to explore and photograph and describe social situations that will be studied thoroughly, broadly and deeply based on data.

A qualitative approach is used by researchers to understand certain situations. In line with Bogdan and Taylor's statement that a qualitative approach is a research procedure that produces descriptive data in the form of written or spoken words from people and 
observable behavior (Bodgan and Taylor in Moleong (2007). This is also conveyed by Moleong that a qualitative approach is research that intends to understand the phenomena experienced by research subjects such as behavior, perception, motivation, action, etc., holistically and by means of descriptions in the form of words and language, in a special natural context and by utilizing various natural methods (Moleong, 2007). So in accordance with the objectives of the study, the method used by researchers is qualitative research methods to identify and obtain an overview of gender dynamics in Islamic law.

\section{Results and Discussion}

In general, gender is the difference that appears between men and women when viewed from values and behavior. So far, gender issues have been dominated by women's perspectives, meanwhile from men's perspectives it has not been widely discussed. Women's perspectives often lead to dead ends in finding the expected solutions, because in the end it ends in problems originating from men. There are several phenomena that often arise in gender issues.

However, the important thing that needs to be done in the study of gender dynamics is to understand the different concepts of gender and sex (gender). Mistakes in understanding the meaning of gender are one of the factors that cause attitudes to oppose or find it difficult to accept gender analysis in solving problems of social injustice. Sex is the difference between men and women based on biological anatomy and is God's nature (Nasarudin, 2001).

According to Mansour Faqih, sex means sex which is a biologically determined distribution of sex which is attached to a certain gender. These biological anatomical differences are irreversible and permanent, natural and non-exchangeable. Therefore, these differences apply throughout the ages and everywhere (Mansour, 1996).

Etymologically gender comes from the word gender which means gender. But Gender is a gender difference that is not caused by biological differences and is not God's nature, but is created by both men and women through a long socio-cultural process. This is in line with Marx's statement which states that an interesting idea that gender differences and inequalities between men and women are not caused by biological differences, but are part of the oppression of the ruling class in production relations which is applied in the concept of family (Marx in Abdul, 2015)

The differences in behavior between men and women, apart from being caused by biological factors, are mostly formed through social and cultural processes. Therefore gender can change from place to place, time to time, even between the socio-economic classes of society (Sunuwati, 2017).

There are also those who argue that gender is the view or belief that is formed by society about how a woman or man should behave or think. For example, the view that an ideal woman must be good at cooking, good at taking care of herself, gentle or the belief that women are sensitive creatures, emotionally always uses feelings. On the other hand, a man is often described as being a leader, protector, head of the household, rational and assertive (Sopyan, 2010).

In general, gender is interpreted as a socio-cultural difference which is a value that refers to a system of social relations that differentiates the functions and roles of women and men due to biological or natural differences which are then standardized by society to become 'cultural' and as if they are no longer negotiable. Gender is a different behavior between men and women, namely differences that are not natural or created by God but are created by men and women through a long social and cultural process. (Dzuhayatin, 2019). 
Gender is a cultural concept that develops in society that seeks to make differences in roles, behaviors, mentality and emotional characters between men and women (Jannah, 2012).

Gender is defined as cultural expectations of men and women. For example; women are known to be gentle, beautiful, emotional and motherly. Meanwhile, men are considered strong, rational, manly and mighty. The characteristics of these traits are interchangeable, for example, there are men who are gentle, there are women who are strong, rational and mighty (Izziyana, 2017). Changes in the characteristics of these characteristics can occur from time to time and from place to place.

The epistemology of gender research in general starts from the paradigm of feminism which follows two theories, namely; structural and conflict functionalism. The flow of structural functionalism departs from the assumption that a society consists of various parts that influence each other, the theory looks for fundamental elements that influence society (Erviana, 2017).

Contemporary functionalist theory focuses on issues of social stability and harmony. Social change is described as natural evolution which is a response to the imbalance between social functions and the structure of social roles. Social change is quickly considered dysfunctional change (Hermanto, 2017).

The value system always works and functions to create a balance in society, for example men as hunters and women as gatherers. Women with reproductive functions demand to be in domestic roles. Meanwhile, men hold public roles. In such a society, the stratification of gender roles is determined by gender. (Yatimin, 2011).

\section{Gender Dynamics in Islam}

Allah created the physical form and character of women to be different from men. Men are given advantages by Allah subhanahu wata'ala both physically and mentally over women so that it is appropriate for men as leaders over women to be found in the Koran in the letter An Nisa ': 35. men. Asy Shaykh Ibn Baaz said: "Islam stipulates that each husband and wife have special obligations so that both of them carry out their roles, so that the building of the community inside and outside the house is perfect (Vanryan, 2020).

Basically, Islam provides equal opportunities for men and women. There are opportunities for women to pursue careers as men are also given the freedom to develop themselves. In Islam, women are allowed to work and develop as widely as possible all their skills (Muzakki, 2016).

Husbands are obliged to earn a living and income while wives are obliged to educate their children, provide affection, breastfeed and care for them as well as other tasks that are suitable for them, teach girls, take care of their schools, and treat them and other jobs specifically for them women. In Islamic law, everything that Allah swt creates is based on their respective kudrat. However, Islam also provides equal opportunities for men and women. There are opportunities for women to pursue careers as men are also given the freedom to develop themselves. In Islam, women are allowed to work and develop as widely as possible all their skills (Kutsiyah, 2019).

The principle of justice is highly respected in Islam. Justice provided by Islam is in the form of equality and equality regarding the rights and obligations of men and women according to their respective responsibilities. So, Islam does not view the rights of men and women as identical or exactly the same. Islam has never embraced preferences and discrimination that benefit men and disadvantage women. Islam also outlines the principle of equality between men and women, but not exactly the same or identical. The word equality (Najamudin, 2019). 
In Islamic law, the Koran and Hadith are used as guidelines to guide and direct people so that they can live a good life without violence, oppression, destruction, threats, or discrimination. Included in this scope are the rules and demands for relationships between men and women (Marlina, 2018). So in the view of Islamic law, when referring to the Qur'an, several principles of gender dynamics are found in Islam:

The last point is specifically related to the world of education where women and men have the same opportunity to be able to actualize themselves in showing their respective competences. In the view of Islamic law, women are required to study knowledge just like men. Islamic law has equated women and men in spiritual matters as well as every religious obligation without any difference (Hasnani, 2014).

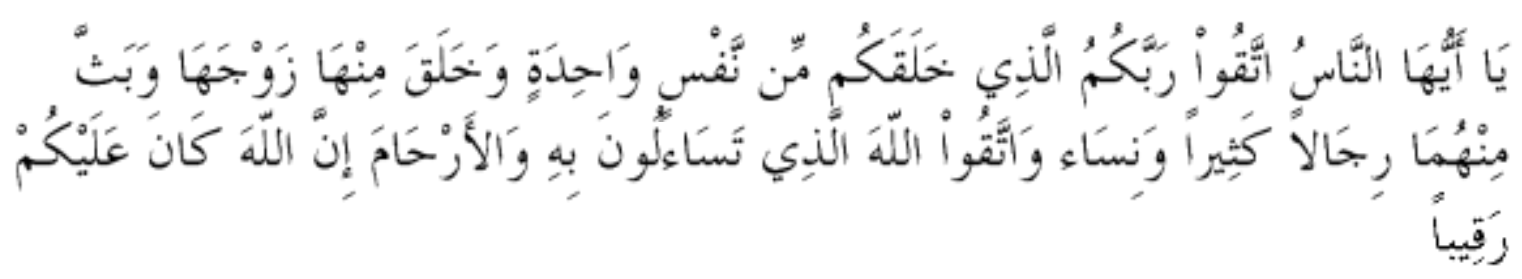

Syeikh Mahmud Syaltut said that the human nature of men and women is different, but it can be ascertained that Allah Almighty bestows more potential and abilities to women as has bestowed them on men. The verses of the Al-Quran which are popularly used as references in discussions about the origin of women's incidents are the words of Allah in QS An-Nisa 'verse 1:

"O all human beings, fear your Lord, who created you from one self (nafs), and from it Allah created a mate and both Allah created many men and women "(Kasmawati, 2013).

The meaning of the nafs here is that according to the majority of tafsir scholars, Adam and his partner are his wife, Siti Hawa. This view then has given rise to negative views towards women by stating that women are part of men. Without male, female does not exist, and not even a few of them think that woman (Eve) was created from Adam's rib. The previous commentaries almost agreed to interpret this (Rakhman, 2019).

Even if the view above is accepted where the origin of the incident of Eve is from Adam's rib, it must be admitted that this is only limited to Eve, because their children and grandchildren, both male and female, come from a combination of sperm and ovum. Allah confirms this in QS. Ali Imran verse 195:

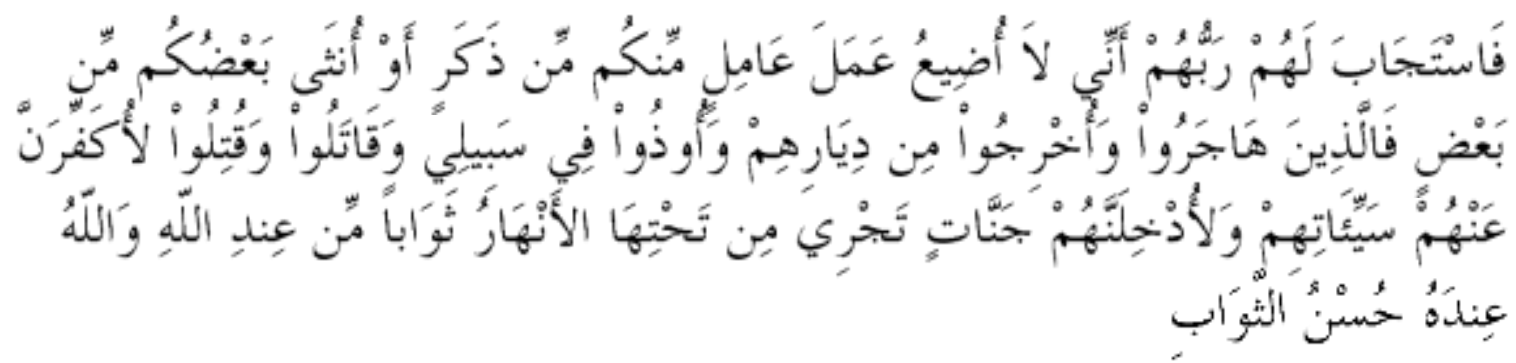

So their Lord allowed his request (saying), "Verily, I do not waste the deeds of those who do good among you, whether male or female, (because) some of you are descended from some of the others. Those who emigrated, who were driven from their hometowns, who were hurt on My path, who fought and were killed, I will certainly erase their mistakes and I will certainly enter them into heaven that flows the rivers below as a reward on their side. Allah. And Allah with Him is a good reward. " (Kasmawati, 2013).

There is no denying that there are differences between men and women because they have their own cudrat. The difference is at least from a biological point of view. Al-Quran reminds: "And do not be jealous of what Allah has given to some of you more than others. 
(because) for men there is a share of what they have earned, and for women (also) there is a share of what they work for, and ask Allah for some of His gifts. Indeed, Allah knows all things ".

The verse above implies a difference, and that each has something special. However, this verse does not explain what the idiosyncrasies and differences are. However, it can be ascertained that the differences that exist certainly result in the main function that they each have to carry out. On the other hand, it can also be ascertained that there is no difference in the level of intelligence and thinking ability between the two sexes.

Islam is a system of life that leads people to understand the realities of life. Islam is also a global order revealed by Allah as Rahmatan Lil 'alamin. So - a logical consequence if Allah's creation of His creatures - male and female - has a mission as khalifatullah fil ardh, who has an obligation to save and prosper nature, to arrive at an awareness of the goal of saving human civilization. Thus, women in Islam have a comprehensive role and equal dignity as servants of Allah and carry the same mandate as men (Ulfah, 2013).

Departing from the above position, the dynamics of women's gender have a very strategic role in educating the ummah, improving society and building civilization, as was done by the shahabiyah in bringing the people who lived in their time to the excellence of civilization. They play a role in their society with high azzam to optimize all the potential that exists in them, so that we do not find even one side of all aspects of their lives being neglected. They play a role in every time, space and stage of their life (Khotimah, 2009).

As a result of an in-depth study of the two areas of study, Riffat concluded that not only in the Islamic tradition, but also in the Jewish and Christian traditions there are three theological assumptions, where the supra structure of male superiority over women (which implies male inequality and women) are enforced. The three assumptions are:

Since women are believed to have been created from male ribs, they are ontologically derivative and secondary. According to Riffat, the creation of Eve from the rib is a belief that is firmly rooted in the Bible and contradicts the Koran. Even if there are 6 (six) prophetic hadiths that support the creation of women from the ribs of men, according to his analysis, they are dho'if because they have a number of narrators that cannot be trusted.

Women are the cause of the expulsion of men from heaven, and not men. Riffat rejects interpretations that always marginalize women. According to him, there is no concept of falling in the Koran, therefore there is no original sin (Maulida, 2018).

Women are created not only from men, but also for men, which makes their existence solely instrumental and has no fundamental meaning. According to Riffat, this opinion contradicts the Koran which explains that human beings were created only to serve Allah and in the best possible form. Men and women are equal before Allah (Heidiyati, 2019).

In the view of feminism, Islam recognizes the term gender - both in classical and modern perspectives. This statement is very basic so as not to create errors and confusion in the paradigm of thinking, it seems that this problem needs to be explained by explaining the methodology of Islam and feminism so that our interpretation of Muslim women in understanding the discourse on the role of women remains within the corridor of a complete Islamic conception (Permana, 2018). The most basic weakness of the theory of feminism is its artificial tendency to modern philosophy. Modern thought has its own logic in looking at reality.

The weakness of this dichotomous becomes fundamental because in modern feminist theory, reality is implicated in the patriarchal system. This was later deconstructed by the post-modernism era with post-structuralism. Post-structuralism dismantles the subjectobject dichotomy or the single truth of a particular subject. So that sexual reality is no 
longer seen only in such a dichotomy, but is seen as a form of plurality with an equal position and each of which has its own truth value (Musyafaa, 2014).

Another weakness is the tools of modern philosophy itself, namely rationalism and imperialism. With its rationalism, modernism relies on the main structure of human subjectivity as the ratio, and embraces subjective forces in the primacy of reason. Meanwhile, empiricism prioritizes sensory and material experience as a measure of truth. Feminism is inseparable from these weaknesses, so that both feminist theory and movement inevitably place themselves in the categorization of the tools of modernism, namely rationalism and empiricism (Ramli, 2010).

Thus in Islamic law, the relationship between humans and other humans as well as human relations with other creatures is the relationship between objects. If there is a human advantage over other creatures, then this is a potential advantage to be prepared for the tasks and functions of humanity as servants (same as jinn, QS 51:56) and khalifatullah (especially for humans QS 2:30). The excess which is required as an excess of knowledge (conceptual) places humans to have a higher ability than the objects of other creatures before Allah. However, this potential advantage can be meaningless when it is not used according to its function or even places humans lower than other creatures (QS 7: 179).

Internal factors which are factors from within women themselves, for example, women always perceive their status as being below that of men, so they do not have the courage and confidence to move forward. External factors are factors that are outside of women themselves, and the most dominant thing is the presence of patriarchal cultural values that dominate all life in the community, so that the role of women is second (Murtadlo, 2018)

Apart from that, there are also gender-biased religious interpretations, general policies, laws and regulations and systems and legal apparatus that are gender-biased and discriminatory, both at the central and regional levels. In addition, the strong culture of the majority of people who consider women to be less active in the public sphere, coupled with the existence of misunderstood religious teachings, make women's struggles to achieve justice and gender equality even more difficult to achieve.

Problems relating to men and women are not easy to be resolved quickly in the community, both broadly and immediately, but it needs a lot of considerations that can provide a basic view of the study, including cultural and religious issues. Therefore gender needs to be discussed in depth, but issues related to religion, especially Islam can be a benchmark in resolving various discrimination problems that often occur in modern social cultures and existing technological developments (Abdul Rahim, 2015).

\section{Conclusion}

Gender is a visible difference between men and women when viewed from values and behavior, gender is a cultural concept, seeks to make distinctions in terms of roles, behaviors, mentality, and emotional characteristics between developing men and women. in society. Inequality of gender dynamics as a problem in the Islamic world, as well as the dark side of behaviors associated with masculine, cannot only be approached from the perspective of women, but must also empathically see it from the male point of view. Gender is an analysis used in placing an equal position between men and women to create a more egalitarian social order. 


\section{References}

Abdul Rahim. Gender dalam Perspektif Islam. Sosioreligius Volume I No. 1 Juni 2015

Abidin, Z. (2017). Kesetaraan gender dan emansipasi perempuan dalam pendidikan Islam. Tarbawiyah: Jurnal Ilmiah Pendidikan, 12(01), 1-17.

Bachtiar, M. (2012). Hukum Waris Islam Dipandang Dari Perspektif Hukum Berkeadilan Gender. Jurnal Ilmu Hukum, 3(1).

Charrad, M. M. (2009). Kinship, Islam, or oil: Culprits of gender inequality?. Politics \& Gender, 5(4), 546.

Charrad, M. M. (2011). Gender in the Middle East: Islam, state, agency. Annual Review of Sociology, 37, 417-437.

Cholil, M. (2013). Psikologi keluarga Islam: Berwawasan gender.

Dzuhayatin,Siti Ruhaini, Rekonstruksi Metodologis Wacana Kesetaraan Gender dalam Islam (Cet. I; Yogyakarta: PSW IAIN Sunan Kalijaga, 2019), h. 18

Erviana, I. (2017). Wanita Karir Perspektif Gender dalam Hukum Islam di Indonesia (Doctoral dissertation, Universitas Islam Negeri Alauddin Makassar).

Hadi, S. (2016). Bias Gender dalam KonstruKsi HuKum islam di indonesia. PALASTREN Jurnal Studi Gender, 7(1), 25-46.

Hasnani Siri. Gender dalam Perspektif Islam. Jurnal Al-Maiyyah, Volume 07 No. 2. 2014. STAIN Parepare

Heidiyati, E. D. (2019). Tradisi Petekan Ngadas Dalam Perspektif Gender, Ham, Hukum Positif Dan Hukum Islam (Studi Di Desa Ngadas Kecamatan Poncokusumo Kabupaten Malang).

Helmi, et al. (2019). Implementation Place of 'Uqubat Canings in Fiqh Perspective (Analysis of Aceh Governor Regulation Number 5 of 2018). Budapest International Research and Critics Institute-Journal (BIRCI-Journal). P. 65-73

Hermanto, A. (2017). Teori gender dalam mewujudkan kesetaraan: menggagas fikih baru. Ahkam: Jurnal Hukum Islam, 5(2), 209-232.

Izziyana, W. V. (2017). Pendekatan feminisme dalam studi hukum Islam. Istawa: Jurnal Pendidikan Islam, 2(1), 139-158.

Jannah, U. S. F. (2012). Pernikahan dini dan implikasinya terhadap kehidupan keluarga pada masyarakat Madura (perspektif hukum dan gender). Egalita.

Kasmawati. Gender dalam Perspektif Islam. Volume 1 Nomor 1 Mei 2013. UIN Alaudin

Khotimah, K. (2009). Diskriminasi gender terhadap perempuan dalam sektor pekerjaan. Yinyang: Jurnal Studi Islam Gender dan Anak, 4(1), 158-180.

Kutsiyah, S. S. A., Faisol, A., \& Asfiyak, K. (2019). Istri karir prespektif kesetaraan gender dan hukum Islam. Jurnal Hikmatina, 1(2), 146-150.

Mansour Faqih, Analisis gender dan Transformasi Sosial, (Yogyakarta: Pustaka Pelajar, 1996), hal. 8

Marlina, S. (2018). Perempuan dan Pilkada Dalam Perspektif Kesetaraan Gender Menurut Hukum Islam. Al-Risalah, 15(01), 8-23.

Maulida, F., \& Busyro, B. (2018). Nafkah Iddah Akibat Talak Bain Dalam Perspektif Keadilan Gender (Analisis Terhadap Hukum Perkawinan Indonesia). Al Hurriyah: Jurnal Hukum Islam, 3(2), 113-130.

Moleong, J Lexy. Metodologi Penelitian Kualitatif. (Bandung, Remaja Rosdakarya, 2007)

Munawarsyah, et al. (2018). Juridical Analysis of the Amount of Diyat Toward Armed Conflict Victims in Aceh. Budapest International Research and Critics InstituteJournal (BIRCI-Journal). P. 104-113 
Murtadlo, M. A. (2018). Keadilan Gender dalam Hukum Pembagian Waris Islam Perspektif the Theory of Limit Muhammad Syahrur. Tafáqquh: Jurnal Penelitian Dan Kajian Keislaman, 6(1), 76-89.

Musda Mulia dkk. Keadilan dan Kesetaraan Gender Perspektif Islam. (Cet. II, Jakarta; Lembaga Kajian agama dan Jender, 2003), h.19

Musyafaâ, N. L. (2014). Studi Hukum Perkawinan Islam di Indonesia Perspektif Gender. Al-Hukama': The Indonesian Journal of Islamic Family Law, 4(2), 409-430.

Muzakki, A. (2016). Sosiologi Gender: Poligami Perspektif Hukum Islam. Lisan Al-Hal: Jurnal Pengembangan Pemikiran Dan Kebudayaan, 8, 353-372.

Najamudin, N. (2019). Analisis Gender dalam Hukum Islam. Tasamuh: Jurnal Studi Islam, 11(2), 381-401.

Nasarudin Umar, Argumen Kesetaraan Gender: Perspektif al-Qur'an, (Jakarta : Paramadina, 2001), hal. 1

Permana, S., \& Martapura, W. K. P. A. (2018). Kesetaraan gender dalam ijtihad hukum waris di Indonesia. Asy-Syari'ah, 20(2), 117-32.

Platt, M. (2017). Marriage, gender and Islam in Indonesia: women negotiating informal marriage, divorce and desire (Vol. 51). Taylor \& Francis.

Rakhman, I. A. (2019). Islam dan Egalitarianisme: Ruang Terbuka Kesetaraan Gender. AtTa'wil, 1(01), 62-73.

Ramli, M. A. (2010). Bias gender dalam masyarakat Muslim: antara ajaran Islam dengan tradisi tempatan. Jurnal Fiqh, 7, 49-70.

Ruble, D. N., Martin, C. L., \& Berenbaum, S. A. (2007). Gender development. Handbook of child psychology, 3 .

Rusli, M. (2011). Konsep Gender Dalam Islam. Kafaah: Journal of Gender Studies, 1(2), 151-158.

Sayidiman Suryohadiprojo, Menghadapi Tantangan Masa Depan, (Jakarta: PT. Gramedia, 1987), hal. 237

Sopyan, Y. (2010). Tarikh tasyri': sejarah pembentukan hukum Islam. Rajawali Pers.

Sunuwati, S., \& Rahmawati, R. (2017). Transformasi wanita karir perspektif gender dalam Hukum Islam (tuntutan dan tantangan pada era modern). An Nisa'a, 12(2), 107-120.

Talbot, M. (2019). Language and gender. John Wiley \& Sons.

Torab, A. (2006). Performing Islam: gender and ritual in Iran. Brill.

Ulfah, I. (2013). Epistemologi Hukum Islam Muslimah Hizbut Tahrir Indonesia (MHTI) di Balik Gagasan Anti Kesetaraan Gender. Justicia Islamica: Jurnal Kajian Hukum dan Sosial, 10(2).

Vanryan, G. L. A., Asfiyak, K., \& Kurniawati, D. A. (2020). Istri Karir Menurut Hukum Islam dan Pespektif Gender. Jurnal Hikmatina, 2(3), 76-86.

Yatimin Abdullah, Studi Islam Kontemporer. (Cet. I; Jakarta: Rajawali Pers, 2011), h. 11 